sciendo Порівняльна професійна педагогіка 8(2)/2018

Comparative Professional Pedagogy 8(2)/2018

DOI: $10.2478 /$ rpp-2018-0020

PhD in Pedagogy, Associate Professor, LARYSA MOVCHAN Vinnytsia Training and Research Institute for Economics, Ukraine Address: 37 Honta St., Vinnytsia, 2100, Ukraine

E-mail: larisa.movchan.ua@gmail.com

\title{
DEVELOPING PROFESSIONAL IDENTITY OF ECONOMICS STUDENTS THROUGH FOREIGN LANGUAGE LEARNING IN UKRAINE AND ABROAD
}

\begin{abstract}
The article tackles the issue of students' professional identity in relation with their motivation towards learning foreign languages (with the focus on English). Modern European education is based on the principle of integrity of the interests of all stakeholders, and future specialists must be ready to meet the challenges of the growing global market. Yet only a small number of Ukrainian school graduates and students of economic universities can communicate fluently in foreign social and communicative spheres. An attempt to find out what hinders the process of foreign language acquisition at non-linguistic universities and what really influences their motivation has been made. The research shows that an important factor in students' motivation towards learning foreign languages is their professional self-identity, which is developed during university study and is in its turn determined by the contents, the form of professional education and the goals set. The analysis of the pedagogical literature has enabled us to formulate the definition of the "professional identity of economics students" content. Thus, it denotes person's professional competencies that help him/her understand his/her role and place in the professional domain, at the job market and in the society on the whole, and also implies motivation, confidence and responsibility as well as readiness to work effectively. Once the student has identified his/her future professional roles, challenges, options and responsibilities he/she is motivated to develop the skills necessary to perform their professional duties and succeed in the career. Economic university training with the global context in mind is a motivating factor of improving foreign language competency of students and a definite factor of economic education prestige.
\end{abstract}

Keywords: economic education, foreign language learning, global context, content and language integrated learning, professional identity, motivating factor.

\section{INTRODUCTION}

With the development of globalization in all spheres of the society, it is becoming inevitable for a country or a person to stay away from this wraparound process. Therefore, it is of utmost importance for Ukraine to create such conditions that its citizens could master foreign languages in the most effective way. Many steps have been made in this direction, especially in secondary education. The authors of school textbooks are constantly improving the content of the texts and various learning activities in order to make them more attractive and informative, thus enhancing pupils' motivation to learning. Foreign languages have been part of the primary school curriculum for over 10 years, the progress and final control over pupils' achievements in FLL (foreign language learning) has been introduced. The span of time pupils are exposed to foreign languages has grown, yet only a small number of school graduates can communicate fluently in a foreign social and 
communicative spheres (Redko, 2005). As a result, when entering a university, the majority of students of non-linguistic faculties do not have well developed language skills to be taught by means of a FL (foreign language). Despite this, a school graduate must reach the level of foreign language competency which is high enough to improve it during the life. This also concerns foreign language competency in a professional specific sphere. Needless to say, foreign language learning is a time consuming process which requires a lot of patience, incorporates various learning methods and forms. Therefore, students' motivation in this respect plays a crucial role.

\section{THE AIM OF THE STUDY}

The purpose of the article is to analyze the concept of professional identity of economics students with relation to their motivation to FLL in Ukraine and in Europe.

\section{THEORETICAL FRAMEWORK AND RESEARCH METHODS}

The issue of student's personal development and self-identity was studied by T. Blease, who showed the role of the teacher in students' identity in the learning process; P. Ackerman, who compared students' personality types and learning modes; P. L. Carell and N. J. Anderson, who proved the correlation between students' personality types and their attitude to FLL. Z. Dornei (2003) showed students' attitudes and motivations in language learning. T. Chamorro-Premuzic and A. Furnham (2005) studied the relation of intelligence and language learning capacity.

Let us consider the concept of student's professional identity. In psychology, a personality is identified as the organized pattern of behaviors and attitudes that makes a human being distinctive. B. Casa and S. Creary (2016) study the construction of professional identity and consider it as an important cognitive mechanism that influences workers' attitudes and behavior in work settings and beyond. They mean that through the construction of a professional identity, individuals are able to claim purpose and meaning for themselves, and explicate how they contribute to society.

M. Larson (1977) is regarded to be among the first to have tackled the issue of professional identity. He suggests that a professional identity must be based on shared expertise incorporating the infrastructure thanks to which practitioners communicate and share ideas, gain experience and knowledge. He also adds that a professional must have advanced training and possess knowledge and skills to perform certain service for the society (Larson, 1977). This opinion is also shared by H. Ibarra, who suggests that a personal identity is developed while socializing with colleagues and observing their work (Ibarra, 1999). G. Imsen (2006) refers motivation to the mixture of feelings, thoughts and reasons which intensifies and ignites our actions (Imsen, 2006). According to recent research (Nearby, 2014), professional identity is defined as the concept which describes how we perceive ourselves within our occupational context and how we communicate this to others (Nearby, 2014).

Thus, we can say that professional identity refers to person's professional competencies, values, motives, confidence and responsibilities that help him/her understand and perform his/her role in the professional domain and in the society on the whole. This notion, in our opinion, also implies readiness to work effectively in order to succeed in a career.

In regard to globalization of economy, a high level of foreign language communicative competency is one of the constituents of the professional portfolio of an economist and this aspect should be a core of economic education. 


\section{S sciendo Порівняльна професійна педагогіка 8(2)/2018}

Comparative Professional Pedagogy 8(2)/2018

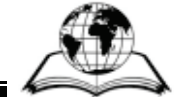

\section{RESULTS}

In this research we will try to show how students' professional identity can motivate them to meaningful foreign language learning. In relation to this goal, we have conducted an empirical research into students' motivation to FLL on the basis of questionnaires and final oral communication. We were interested both in lingual methodological and social factors. The research involved 80 students (4 groups) of specialties: "Audit and taxation", "Economics", "Finance and crediting" and "Entrepreneurship and brokerage". The empirical study involved students of the $1^{\text {st }}$ and the $2^{\text {nd }}$ years of study. We also conducted additional monitoring of $3^{\text {rd }}$-year students' foreign language oral performance just to compare their further development.

The questionnaires were worked out on the basis of theoretical analysis of research on this issue. On the basis of these questionnaires we distinguished the crucial motivating factors and compared them to those of foreign students. Students were asked the following questions:

1) What are the main difficulties in language acquisition?

a) grammar, b) words, c) pronunciation, d) listening.

2) What are the main fears of language use?

a) grammar, b) words, c) phrasal verbs and idioms, d) oral communication.

3) Which spheres do students feel more confident?

a) reading, b) listening, c) writing.

4) What is the most attractive about language learning? exercises.

a) interesting texts, b) communicative interaction, c) grammar exercises, d) lexical

5) What positively influences students' performance in foreign language learning?

a) interesting texts, b) communicative interaction, c) teacher's qualities, d) language environment.

6) What demotivates students in FLL?

Students' responses showed that while learning a FL they face such difficulties as grammar $-44 \%$, memorizing new words and learning their use $-11 \%$, pronunciation (relating English) - $14 \%$, listening - $41 \%$ (Fig. 1). English grammar has always been considered difficult to learn because of absence of some tense forms in the Ukrainian language, and some seemingly odd language use. Some students find it very difficult to understand oral speech in TV reports, dialogues of native speakers, songs. This can be however rectified by the knowledge of grammar and words. Our study shows that students, who knew grammar and words better, performed better in listening comprehension.

\section{Difficulties the students face while learning English}

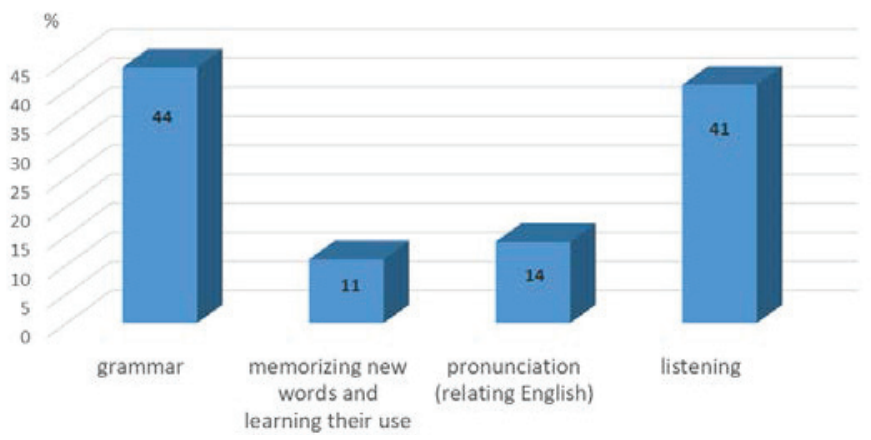

Fig. 1 
These findings also mirror the second question: What are the main fears of language use:

a) grammar, b) words, c) phrasal verbs and idioms, d) oral communication?

Students' answers showed that students feel uncertain about finding the right word - $32 \%$ and $18 \%$ - about grammar. They tend to believe that words are more important than grammar. However, students' attitude towards knowing phrasal verbs and idioms seemed to be unclear, regarding them as unnecessary. $35 \%$ of students have fear for using phrasal verbs being uncertain about the use of common words and grammar. $25 \%$ of students are unwilling to participate in oral communication for the fear of making mistakes. But our observations at the lessons showed that this figure was slightly exaggerated, about $18 \%$ of students with a low level of foreign language competency refrained from producing oral messages. And $44 \%$ of students are uncertain about comprehending oral messages correctly for the insufficient knowledge of grammar and words (Fig. 2).

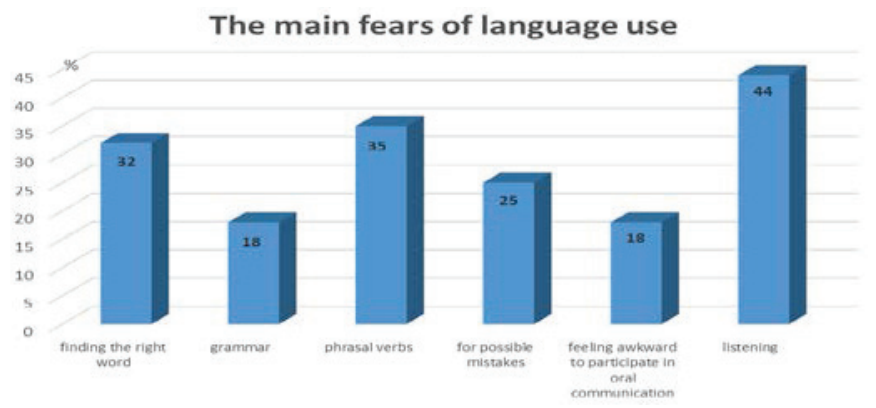

Fig. 2

All mentioned above testifies to the students' uncertainty about their language competency and progress in the language. They find it difficult to identify themselves in the language study process.

In this respect, we can refer to G. Sultana (2009) who views competency as a set of theoretical knowledge and practical skills. Skills can be developed in the process of meaningful repetitive actions, which, judging from the current curriculum for economic universities, is hardly possible for the shortage of academic time allotted for the study of foreign language for specific purposes.

When asked: "Which sphere do you feel more confident in?":

a) reading, b) listening, c) writing, d) speaking, students answered that they felt more confident in reading $(100 \%)$, fewer students $(60 \%)$ felt confident in speaking, $56 \%$ - in listening and only $18 \%$ admitted to being able to produce written speech (Fig. 3). These figures show that students feel more confident in passive activities such as reading and listening and less certain about their abilities to communicate ideas either orally or in writing.

This all testifies to the insufficient students' exposure to the foreign language. Little time is spent in a FL class (we have mentioned the deficiency of academic time for FLL in the curriculum of higher educational establishments) and students misunderstand the role of independent study at home. For instance, it comprises almost half of the academic time allotted in the curriculum (109 hours out of 240), yet this time is mostly wasted. The academic load for learning FL at Ukrainian high school makes up about 240270 hours per 2 years which is 2 hours or one lesson a week. As compared with the 
Sciendo Порівняльна професійна педагогіка 8(2)/2018

Comparative Professional Pedagogy 8(2)/2018

bachelor program of economics at the Stockholm School of Economics, foreign languages do not stand separately in the curriculum and international or global context of future employment is underpinned in most special courses such as "Shaping markets for growth", "Acting in an uncertain world", "Entrepreneurship in Developing Countries", "International Financial Management", "Advanced Analysis of China's Political Economy", "Economic \& Political Analysis of Emerging Markets", "Japan in the Global Economy: Advanced Analyses" (Stockholm School of Economics, 2017).

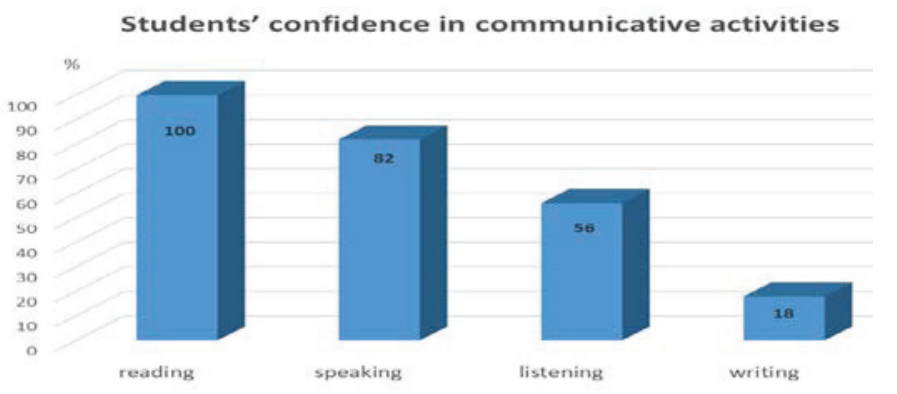

Fig. 3

This tendency is also traced at the Economic University of Vienna that offers such courses as "International Economy of Enterprise", "Global Marketing". Moreover, the program "Business and Economics" is taught in English and is aimed at giving students the understanding of economy in the global context, how to deal with contemporary economic challenges, develop important interdisciplinary skills and abilities as well as to help students' pursue their personal interests (Wirschaftsuniversität Wien, 2017). It means that students identify themselves as participants of the global economic processes, which motivates them to develop their communicative competency in a FL. These courses give them awareness of the international context of the economy and their role in its development, for they already know how to apply their knowledge, skills and abilities. This fact is extremely important for the students' professional identity, which is a motivating factor for improving their FL communicative skills and their personal and professional development on the whole.

Courses offered in English also create the artificial language environment which also aids in students' professional self-identity.

As we know, motivation is determined by internal and external factors. Students' professional identity is an internal factor of motivation to FLL, as they take responsibility for their performance. Professional self-identity embraces students' understanding of their future professional responsibilities and needs, job requirements and challenges they will be able to cope with due to the command of a FL. In a broader meaning, professional selfidentity as a motivating factor to FLL may include willingness to perform better than others and be more successful, the need to extend professional knowledge, be mobile at the global labour market, desire to travel around the world and to learn foreign life style. To the external factors of students' motivation to FLL we may refer:

- learners' linguistic self-confidence;

- interesting language classes;

- students' autonomy;

- personalization of the learning process; 
- increase the learners' goal-orientation (Zoltan, \& Csizer, 1998);

- increase of students' exposure to FL due to creation of the artificial FL environment due to content and language integrated learning at the university;

- tutor-guided FL classes at universities.

In this respect we may admit that few Ukrainian universities practice tutor-guided lessons, at which each student's development in a FL is well observed, controlled and directed. The lack of language environment adds to the problem being very important for FL acquisition.

R. Ellis (1994) also distinguishes social factors that influence both students' performance and motivation towards FLL: age, gender, social class and ethnic identity (Ellis, 1994). We tried to ask some students of all groups under survey about their social background (professions or occupations of their parents), since they were of the same age and ethnicity. We did not notice any significant difference in student's motivation towards language learning, however their performance differed. Students from rural areas who for some reasons had not obtained good FL competency at school, lost interest in the language because of its complexity, did not perform well in comparison with those who had a possibility to complementary study. Thus, social circumstances and environment play a vital motivating role and influence students' language acquisition.

Besides, all surveyed students admitted to the role of a FL teacher in their interest in the language. They also admitted to perceiving information and performing better when guided by a teacher who has personal qualities of a leader, facilitator and coordinator $(78 \%)$. Only $57 \%$ of students admitted that interesting texts can motivate them to study a FL, while interaction in class seems more engaging $(83 \%)$. All the students admitted to the language environment as a crucial factor in language learning, while it promotes memorizing new words and word combinations, development of communicative skills and overall provides a better language exposure.

Furthermore, when preparing each lesson a teacher must consider the fact that students find communicative interaction more attractive (92\%) in FLL than grammar or lexical exercises $(4 \%)$, however interesting informative texts are useful when understandable $(95 \%)$.

What concerns demotivating factors of FLL, $76 \%$ of students admitted to being uncertain about the use of a FL in their future career. This fact holds true when the situation at the job market is far from optimistic. First of all, a university diploma in Ukraine does not guarantee employment according to the qualification or appropriate payment. It doesn't guarantee employment abroad which implies the necessity in mastering a FL, either.

Another demotivating factor that we found out while surveying the students' opinions, was the lack of language environment, no need to use the language in everyday or professional life. Despite the fact that Ukrainian universities holding students' scientific conferences recommend writing theses in three or even more languages, this practice for non-linguistic students is occasional.

Let us consider the situation in the EU countries. For instance, Scandinavian countries prioritize the knowledge of English for a successful career, education and tourism. In Sweden English has been the first foreign language at schools since 1960. Likewise, it is the only language that is mandatory throughout compulsory school and, as one of the core subjects along with Swedish and Mathematics, a pass grade is required to proceed to the upper secondary level (Sundqvist, \& Sylven, 2014). Moreover, its 
sciendo Порівняльна професійна педагогіка 8(2)/2018

Comparative Professional Pedagogy 8(2)/2018

importance in all social domains is underlined in every possible way. English as a language and as a means for cultural expression can be found all over Swedish society and in several areas English is the commercial language. Hence, to remain independent in an interdependent world, understanding and using English is essential (Skolverket, 2011). School must ensure that pupils are motivated to learn English as well as other FLs throughout their lives. Furthermore, English exam at the level B2 (according to CEFR) is obligatory for the enrollment to the university in Sweden. In this way, we trace the remarkable integrity of the secondary and higher education. Having developed effective communicative skills in English at school, upon enrollment, students can do well in vocationally oriented English or even be taught by its means, for the practice of content and language integrated learning is very common both at secondary and higher education.

Another factor for professional identity is a sociocultural aspect of FLL. It must be realized in the content of the textbooks, audiovisual materials, handouts etc. Therefore, students of Stockholm School of Economics while studying economies of developed and developing countries learn their social and cultural traditions. This awareness brings them closer to the social life of people of these countries and gives them understanding of existing problems and needs as well as reasons of their economic success.

Another example is the University of Applied Sciences, FH, Upper Austria, where within the frames of the Bachelor's program for "Controlling-rechnungswesen-undfinanzmanagement" (Controlling, accounting and financial management) some social and cultural aspects of foreign countries are embedded into the syllabi of the subjects: "Internationale Rechnungslegung" (International Accounting), Sozialkompetenz (Social Competency), Sozialkompetenz Vertiefung (Advanced Social Competency), Englisch Vertiefung (Advanced English) (University of Applied Sciences, 2017). Students also take practice at enterprises, analyzing their accounting documentation and upon the completion of the practice they write project papers in English, followed by presentations and discussions in groups of teachers, students and chief executives of the enterprises (University of Applied Sciences, 2016).

Needless to say, while writing the project paper on accounting students learn how to use specific terms in English, they learn academic writing and oral speaking. These activities are very important for students' professional self-identity, as making reports and substantiating one's own opinions by means of English give them awareness of many industrial processes and accounting procedures, thus increasing their confidence in their own skills and abilities, motivation to language use and improvement of FL communicative competence.

Another motivating factor of FLL and professional self-identity is the possibility to study abroad. For instance, the bachelor and master programs of economic specialties of the University of Oslo (Norway), the University of Applied Sciences, FH (Austria), The Stockholm School of Economics recommend that students go on exchange to foreign countries and take courses that can be approved as optional or mandatory. Suffice it to mention, that the University of Oslo offers 800 courses taught in English both for Norwegian and foreign students (University of Oslo, 2017).

In our opinion, Ukrainian students lack such experience, which is necessary for their professional self-identity and motivation to learn FL. So what should be done to improve the situation? In our opinion, it could be very positive to create the proper basis and start introducing content and language integrated learning that will help create artificial language environment. Students should be stimulated to develop academic writing skills in 
English or other FL through involvement in a project or thesis writing, participating at conferences. Such activities will increase students' exposure to the FL and give them more awareness of their involvement.

Secondly, students must be aware that they belong to the global processes and will be able to enter a global labour market. Thus, the level of their professional competency must correspond to that of foreign students. It means that they should be able to operate by means of English or other FL, communicate ideas, participate in production meetings, make telephone or video calls. Therefore, socio-cultural aspect of language learning must be in focus of attention during FL classes, for the students should be familiarized with new sociocultural settings and know what for and how they will apply their FL skills.

\section{CONCLUSIONS}

Professional self-identity of economics students underpins the whole system of higher economic education and influences its success, for it creates the basis for students' professional image, their vision of professional activities and future career on the whole. In conditions of the global market economic students should be trained for the global business, dealing with surging and stagnating economies, converging economic interests. A good command of English and other foreign languages has become an inseparable part of the professional image of a modern economist in the world and should be attributed to Ukrainian students of economics. This requirement can be fulfilled through students' understanding the purpose and role of economic education and envisaging their own role in the global economic and social processes. It causes the convergence of the content and form of economic education that would help students identify themselves as specialists for the global economy and increase students' motivation to learning foreign languages for the creation of a successful professional profile. In our opinion, modern economic education should be based on the consideration of these two important directions that determine professional self-identity of students and influence the quality of education, the level of their professionalism and success in career.

\section{REFERENCES}

1. Casa, B., \& Creary, S. (2016). The construction of professional identity. Cornell University School of Hotel Administration: The Scholarly Commons.

2. Dorney, Z. (2003). Attitudes, orientations, and motivations in language learning: advances in theory, research, and applications. Language Learning. A Journal on Research in Language Studies, 53 (S1), 3-32.

3. Ellis, R. (1994). The study of second language acquisition. Oxford: Oxford University Press.

4. Ibarra, H. (1999). Provisional selves: experimenting with image and identity in professional adaptation. Administrative Science Quarterly, 44, 764-791.

5. Imsen, G. (2006). Elevens värld, Introduktion i pedagogisk psykologi. Lund: Studentlitteratur.

6. Larson, M. S. (1977). The rise of professionalism. Berkeley, CA: University of California Press. Retrieved from http://www.healthofchildren.com/P/Personality-Development. html\#ixzz52wh9muxE.

7. Neary, S. (2014). Professional identity: what I call myself defines who I am. Career Matters, 2 (3), 14-15. 
8. Schein, E. H. (1978). Career dynamics: matching individual and organizational needs. Massachusetts: Addison-Wesley.

9. Skolverket, S. (2011). Kommentarmaterial till kursplanen i engelska. Stockholm: Fritzes.

10. Stockholm School of Economics. (2017). Economic \& political analysis of emerging markets. Course 5317 description. Retrieved from: $\backslash$ https://pcw.hhs.se/courses/ 5317.

11. Sultana, R. G. (2009). Competence and competence frameworks in career guidance: complex and contested concepts. International journal for education and vocational guidance, 9, 15-30.

12. Sundqvist, P., \& Sylvén, L. K. (2014). Language-related computer use: focus on young L2 English learners in Sweden. ReCALL, 26 (1), 3-20.

13. University of Applied Sciences. (2016). Bachelor programs in Wirtschaftslehre. Retrieved from http:/www.fh-ooe.at/campus-steyr/studiengaenge/bachelor/ controlling-rechnungswesen-und-finanzmanagement/alle-infos-zum-studium/studienplanvollzeit.

14. University of Oslo. (2017). Master program in Economics. Retrieved from http://www.uio.no/english/studies/programmes/economics-master/structure/.

15. Redko, V. H. (2012). Zasoby formuvannya kommunikatyvnoiy kompetentnosti u zmisti shkilnykh pidruchnykiv z inozemnykh mov. Teoria i praktyka. Kyiv: Geneza.

16. Wirtschaftsuniversität Wien. (2017). Business and economics. Syllabus content and structure for 2018/19. Retrieved from https://www.wu.ac.at/studium/bachelor/ businessand-economics/overview/.

17. Zoltan, D., \& Csizer, K. (1998). Ten commandments for motivating language learners: results of an empirical study. Language Teaching Research, 2/3, 203-229. 